\title{
Assessing the neutralisation, wet deposition and source contributions of the precipitation chemistry over Europe during 2000-2017
}

Ágnes Keresztesi ${ }^{1,2,4}$, Marius-Victor Birsan², lon-Andrei Nita ${ }^{2,3}$, Zsolt Bodor ${ }^{4}$ and Róbert Szép ${ }^{1,4,5^{*}}$ (1)

\begin{abstract}
Background: The chemical composition of precipitation was assessed in 27 European countries from 2000 to 2017, offering a general point of view on the rainwater chemistry in Europe, contributing to a larger understanding of air pollution and atmospheric chemistry.
\end{abstract}

Results: The volume-weighted mean concentrations (VWM) were calculated, showing the relative dominance of $\mathrm{SO}_{4}^{2-}$ and $\mathrm{Cl}^{-}$, explaining the acidic and slightly acidic $\mathrm{pH}$ values that ranged from 4.19 to 5.82 over Europe. The VWM concentrations of ionic species measured in rainwater usually followed the $\mathrm{SO}_{4}^{2-}>\mathrm{Cl}^{-}>\mathrm{Na}^{+}>\mathrm{NH}_{4}^{+}>\mathrm{NO}_{3}^{-}$ $>\mathrm{H}^{+}>\mathrm{Ca}^{2+}>\mathrm{Mg}^{2+}>\mathrm{K}^{+}>\mathrm{HCO}_{3}{ }^{-}$downward order, with small exceptions, depending on the industrial activity or legal framework of a particular area. Fractional acidity showed that $\sim 69 \%$ of the inorganic acidity in precipitation is neutralised, whilst neutralisation factors showed that $\mathrm{Na}^{+}$and $\mathrm{NH}_{4}{ }^{+}$contributed the most to the neutralising process. The relationship between acidic and neutralising compounds was further examined by calculating the ionic ratios. Wet deposition rates showed the dominance of acidic compounds over neutralising ones, reflecting the climatic influences and the local and regional economic characteristics of different regions from Europe. Origins of major ions in rainwater were examined using the sea salt and non-sea salt fractions, crustal and marine enrichment factors, correlation analysis and the Principal Component Analysis, showing the significant influence of anthropogenic sources (industry, agriculture, traffic). Natural sources (maritime, terrestrial) also play a major role in influencing the precipitation chemistry of the European continent.

Conclusions: The main conclusion of this study regarding the precipitation chemistry of the European continent during the studied period is represented by the relative homogenous distribution of the analysed chemical species, which is most likely due to the unitary economic development and to the implementation of common European policies in the field of environmental protection. Since the $\mathrm{pH}$ is still acidic due to the anthropogenic emissions, more attention should be given to the implementation of environmental legislation, especially in non-European Union countries or in countries that joined recently.

Keywords: Rainwater, Chemical composition, Acid rain, Neutralisation, Wet deposition, Source contribution

\footnotetext{
${ }^{*}$ Correspondence: szeprobert@uni.sapientia.ro

${ }^{4}$ Department of Bioengineering, Faculty of Economics, Socio-Human

Science and Engineering, Sapientia Hungarian University of Transylvania,

Piaţa Libertăţii 1, 530104 Miercurea Ciuc, Romania

Full list of author information is available at the end of the article
}

Springer Open

(C) The Author(s) 2019. This article is distributed under the terms of the Creative Commons Attribution 4.0 International License (http://creativecommons.org/licenses/by/4.0/), which permits unrestricted use, distribution, and reproduction in any medium, provided you give appropriate credit to the original author(s) and the source, provide a link to the Creative Commons license, and indicate if changes were made. 


\section{Background}

The assessment of precipitation chemistry provides important insights on the chemical composition of the atmosphere, taking under account numerous influencing factors, such as the type and distribution of aerosol sources, chemical species, long-range transport of air pollutants and the origin of air masses. Rainwater chemistry was intensely studied worldwide over the past 30 years [1-10], since by determining the chemical composition of precipitation the contributing sources can be identified, understanding the local and regional dispersion of pollutants and their potential effect on the environment through scavenging and deposition processes [11].

The present study assesses the European precipitation chemistry of the last 18 years, during 2000-2017, contributing to better understand some environmental issues, related to air pollution and the chemical composition of the atmosphere. As presented in the study of Vet et al. [8], since 1995 three main studies were published that assessed the global precipitation chemistry, mainly focusing on the wet and dry deposition. In 1996, the World Meteorological Organization released a report [12] that provided a global assessment on the acidic deposition, that was summarised into a publication a year later [13], showing that regions with highest precipitation concentrations and deposition fluxes of sulphate and nitrate coincide with the regions where the highest density of $\mathrm{SO}_{2}$ and $\mathrm{NO}_{x}$ precursor emissions can be observed. In 2006, Dentener et al. assessed the deposition of nitrogen and sulphur on a regional and global scale, combining measurements with the ensemble mean modelling results of 21 Eulerian (fixed grid) global models used to simulate chemical fate and transport in the atmosphere [14]. The third study [8] is a global assessment of precipitation chemistry and deposition, that has been carried out under the direction of the World Meteorological Organization (WMO) Global Atmosphere Watch (GAW) Scientific Advisory Group for Precipitation Chemistry (SAG-PC), with the objective to characterise the chemical composition of precipitation and deposition (wet, dry, total) for sulphur, nitrogen, acidity, sea salt, mineral base cations, organic acids and phosphorus on global and regional scales, over 2 time-periods: 2000-2002 and 2005-2007 [8]. Regarding acidifying compounds, over the European continent, there have been significant reductions (of the order of $70-90 \%$ ) in ambient concentrations and deposition of sulphur during the last three decades [8]. Due to the considerable reductions in $\mathrm{SO}_{x}$ emissions, $\mathrm{NO}_{x}$ have become the principal acidifying compounds [15]. As a consequence of declining sulphur emissions in Europe, acidification is slowly declining and some forests and lakes are showing signs of recovery $[15,16]$. According to the European Monitoring and Evaluation Programme (EMEP) in 2017, hotspots of exceedances regarding acidification occurred in the Netherlands and its areas that border Germany and Belgium, as well as in southern Germany. All over the European continent, acidity exceedances occur in about $5.3 \%$ of the ecosystem area [17]. It is projected that in 2020 only $4 \%$ of the European ecosystem area will exceed the acidification critical loads if current legislation is fully implemented [15].

The objective of the present study is to distinguish the characteristics of the chemical composition of precipitation, including major ions, the variation of $\mathrm{pH}$, sea salts, the neutralising capacity, enrichment factors, wet depositions and source contributions in 27 countries from Europe between 2000 and 2017, including: Austria, Belarus, Croatia, Czech Republic, Denmark, Estonia, Finland, France, Germany, Greece, Hungary, Iceland, Ireland, Italy, Latvia, Netherlands, Norway, Poland, Portugal, Serbia, Slovakia, Slovenia, Spain, Sweden, Switzerland, Turkey and the United Kingdom. The above-mentioned countries were separated into regions as follows: East Central Europe (Belarus, Czech Republic, Hungary, Poland, Slovakia); Northern Europe (Denmark, Estonia, Finland, Iceland, Ireland, Latvia, Norway, Sweden, United Kingdom); Southern Europe (Croatia, Greece, Italy, Portugal, Serbia, Slovenia, Spain, Turkey); and Western Europe including Austria, France, Germany, Netherlands and Switzerland. The study not only reflects on the homogeneity and the differences that can be found between countries and regions, due to different environmental policies, but also takes under consideration the overall characteristics of precipitation chemistry over the European continent. This assessment offers a general point of view of the rainwater chemistry in Europe, and as far as the authors know, such a long-term study summarising the characteristics of chemical composition of rainwater in Europe has not been done yet.

\section{Data and methods}

The precipitation chemistry data used in the present study rely on national and regional monitoring methods and networks [8], and were downloaded from the GAW World Data Centre for Precipitation Chemistry, that is publicly available at http://wdcpc.org. The annual data of precipitation amount used in this study were extracted from E-OBS raster dataset (version 19.0). Data have been aggregated on an annual basis, and then extracted using the mean value for each country's polygons. E-OBS data are freely available at http://www.ecad.eu [18].

Regarding major ions, from the downloaded database the following cations and anions were used in further calculations: $\mathrm{Na}^{+}, \mathrm{K}^{+}, \mathrm{Ca}^{2+}, \mathrm{Mg}^{2+}, \mathrm{NH}_{4}{ }^{+}, \mathrm{Cl}^{-}, \mathrm{SO}_{4}{ }^{2-}$, 
$\mathrm{NO}_{3}{ }^{-}$, whilst $\mathrm{HCO}_{3}{ }^{-}$and $\mathrm{H}^{+}$concentrations were determined based on the empirical relationship between $\mathrm{pH}$, $\mathrm{HCO}_{3}{ }^{-}$and $\mathrm{H}^{+}$, respectively, using the following equations [19-21]:

$$
\begin{aligned}
& {\left[\mathrm{HCO}_{3}^{-}\right]=10^{-11.24+\mathrm{pH}}(\mathrm{eq} / \mathrm{l}),} \\
& {\left[\mathrm{H}^{+}\right]=10^{-\mathrm{pH}}(\mathrm{eq} / \mathrm{l}) .}
\end{aligned}
$$

For all 27 countries during 2000 and 2017, a total number of 4409 data were processed, having in average from 3 to 48 measurements/year/country in the downloaded database. For each country the mean value was calculated, resulting in one value/year/country and 450 data in total. To ensure the quality and reliability of the data used in the study, collected data were screened and analysed for the entire 18-year period, calculating the ionic balance, which was used as an indicator of the completeness of the measured major constituents [22]. The dataset is considered acceptable if the equivalent ratio of the sum of the anions to the sum of the cations $(\Sigma$ anions $/ \Sigma$ cations) is within the range of $1 \pm 25 \%[10,23]$.

Assuming that the observed cation/anion deficiency found in the measured samples is due to the presence of $\mathrm{H}^{+}$and $\mathrm{HCO}_{3}{ }^{-}$, respectively, the ionic balance was recalculated (taking under consideration the concentrations of $\mathrm{H}^{+}$and $\mathrm{HCO}_{3}{ }^{-}$) showing values that ranged between 0.90 in Estonia and 1.22 in Hungary, with an average of 0.98 . Additional ionic imbalances may be due to unmeasured organic acids in rainwater [22], such as $\mathrm{HCOO}^{-}$, $\mathrm{CH}_{3} \mathrm{COO}^{-}, \mathrm{C}_{2} \mathrm{O}_{4}{ }^{2-}, \mathrm{F}^{-}$and $\mathrm{PO}$, which were not been measured and data regarding any organic acids were not available. After rejecting the data that have not met the quality criteria, linear regression analysis was performed between the grand total anions' concentration and the grand total cations' concentration for Europe and each region, respectively. Strong correlations were obtained between the sum of anions and the sum of cations in each case, the $\mathrm{R}^{2}$ value being $0.68,0.75,0.80,0.53$ and 0.67 for Europe (EU), Central East Europe (CE-EU), Northern Europe (N-EU), Southern Europe (S-EU) and Western Europe (W-EU), respectively (Fig. 1).

\section{Results and discussion}

\section{Chemical composition of rainwater}

To assess the ionic composition of precipitation, the volume-weighted mean (VWM) along with statistical analysis including standard deviation, standard error, mean, minimum and maximum was performed in case of all 27 countries from Europe. Figure 2 shows the spatial variability of the chemical composition of rainwater around Europe for the 2000-2017 period. The volume-weighted means of major ions at each country are represented by a coloured bar chart, on a linear scale. The VWM concentrations of the ionic species measured in rainwater usually followed the $\mathrm{SO}_{4}{ }^{2-}>\mathrm{Cl}^{-}>\mathrm{Na}^{+}>\mathrm{NH}_{4}{ }^{+}>\mathrm{NO}_{3}{ }^{-}>$ $\mathrm{H}^{+}>\mathrm{Ca}^{2+}>\mathrm{Mg}^{2+}>\mathrm{K}^{+}>\mathrm{HCO}_{3}{ }^{-}$downward order, with small exceptions, depending on the industrial activity or legal framework of a particular area. Amongst the analysed cations and anions, $\mathrm{SO}_{4}{ }^{2-}$ presented the highest VWM concentration in all 27 countries, ranging between $40.60 \mu \mathrm{eq} \mathrm{L}^{-1}$ in Spain and $48.38 \mu \mathrm{eq} \mathrm{L}^{-1}$ in Latvia, being followed by $\mathrm{Cl}^{-}$and $\mathrm{Na}^{+}$. The average $\mathrm{SO}_{4}{ }^{2-}$ concentration for Europe represented $21.48 \%$ and $43.51 \%$ of the total ions and anions measured, respectively. In average, amongst the total measured ions $\mathrm{Cl}^{-}$accounted for $16.24 \%$, whereas amongst anions represented $32.89 \%$.

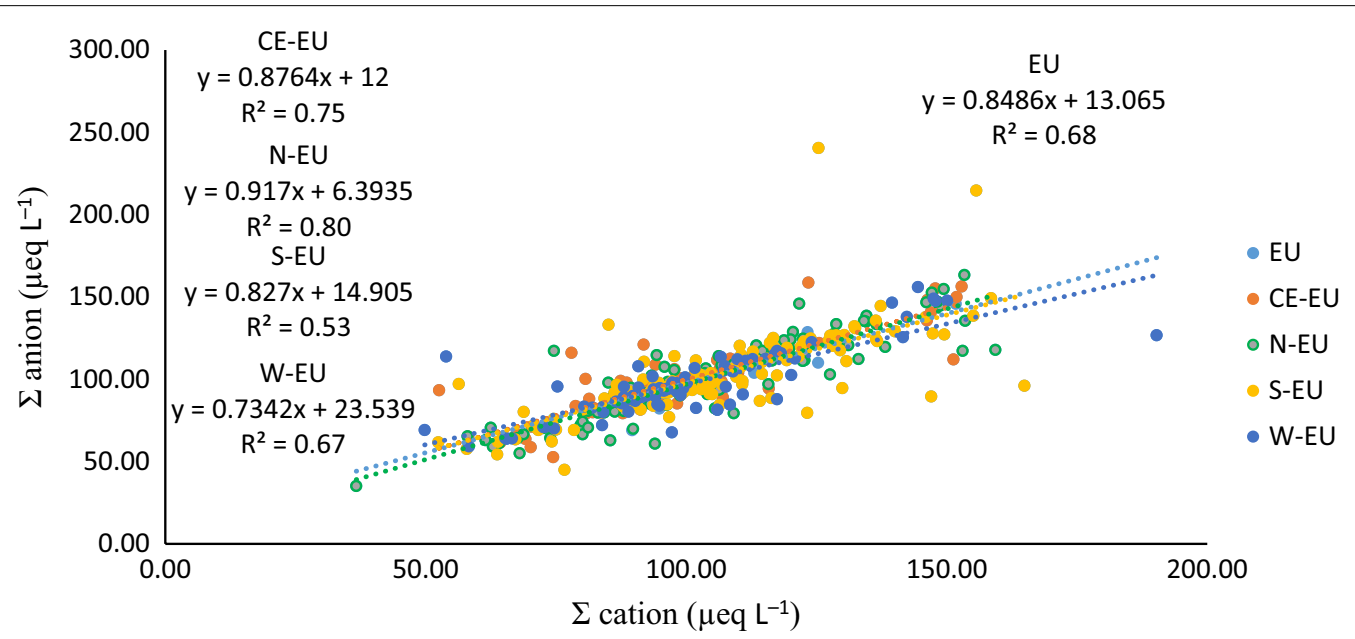

Fig. 1 Relationship between the sum of cations and anions $\left(\mu e q \mathrm{~L}^{-1}\right)$. Linear regression analysis between the sum of anions and cations for Europe (EU), Central East Europe (CE-EU), Northern Europe (N-EU), Southern Europe (S-EU) and Western Europe (W-EU), respectively 


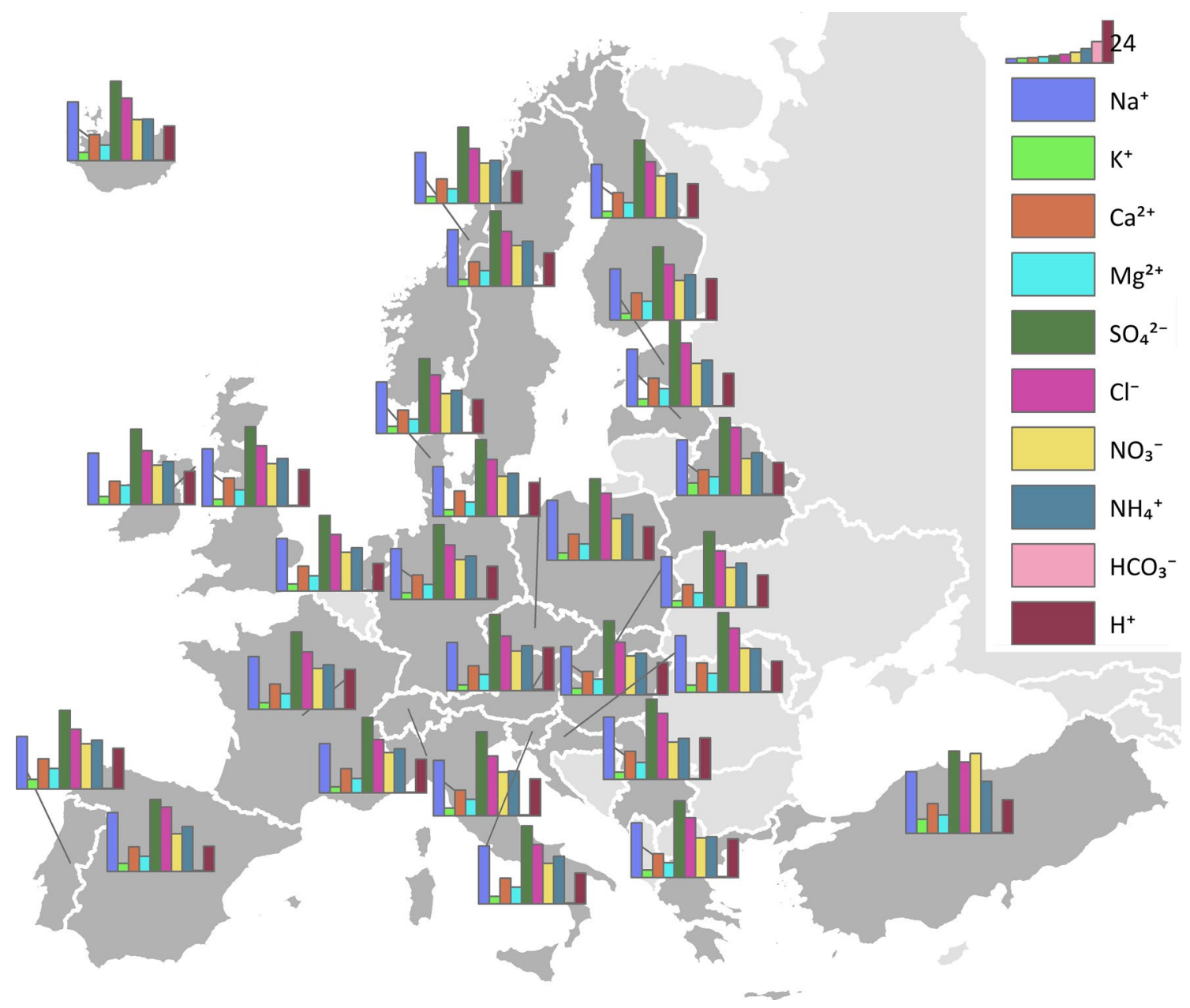

Fig. 2 Volume weighted means of major ions in precipitation. The spatial variability of the chemical composition of rainwater around Europe for the 2000-2017 period. The volume-weighted means of major ions at each country are represented by a coloured bar chart

$\mathrm{Na}^{+}$appeared to be the most abundant cation, contributing with $14.95 \%$ and $29.54 \%$ to the total mass of ions and cations, respectively. In all cases, $\mathrm{Na}^{+}$was followed by $\mathrm{NH}_{4}^{+}$.

The lack of significant differences between VWM concentrations amongst the studied European countries shows the homogeneity of the analysed data, indicating that the use of common environmental policies and industrial emission regulations resulted in low variability regarding pollutant concentrations at a regional level; additional dissimilarities only occurring at a local level, fact that can be observed in the ionic composition of precipitation.

\section{Variation of $\mathrm{pH}$}

The $\mathrm{pH}$ values of precipitation in Europe ranged from 4.19 to 5.82 , with an average value of 4.80 . The occurrence of such low $\mathrm{pH}$ values can be explained by the high concentrations of acidic species derived from $\mathrm{SO}_{4}{ }^{2-}$, $\mathrm{Cl}^{-}$and $\mathrm{NO}_{3}{ }^{-}$, and the lower concentrations of neutralising cations such as $\mathrm{Ca}^{2+}, \mathrm{Mg}^{2+}$ and $\mathrm{NH}_{4}{ }^{+}$. According to the specialty literature, water in equilibrium with an unpolluted atmosphere containing $\mathrm{CO}_{2}, \mathrm{NO}_{x}$ and $\mathrm{SO}_{2}$ is slightly acidic with a $\mathrm{pH}$ value around $5.6[22,24,25]$. Therefore, precipitation with a $\mathrm{pH}$ below this value is usually considered acidic, showing the influence of heavy anthropogenic emissions of $\mathrm{SO}_{2}$ and $\mathrm{NO}_{2}$, originating mainly from industrial activities, coal burning and the cold start of vehicles [24]. The average percentage distribution of $\mathrm{pH}$ values in case of the studied countries indicates a higher level of acidity, about $94.44 \%$ of the samples having $\mathrm{pH}$ values lower than $5 ; 5.11 \%$ between 5 and 5.6; whilst only $0.44 \%$ of the data fall in the range between 5.6 and 6 (Fig. 3). At regional scale, some differences can be observed regarding the variation of $\mathrm{pH}$. 


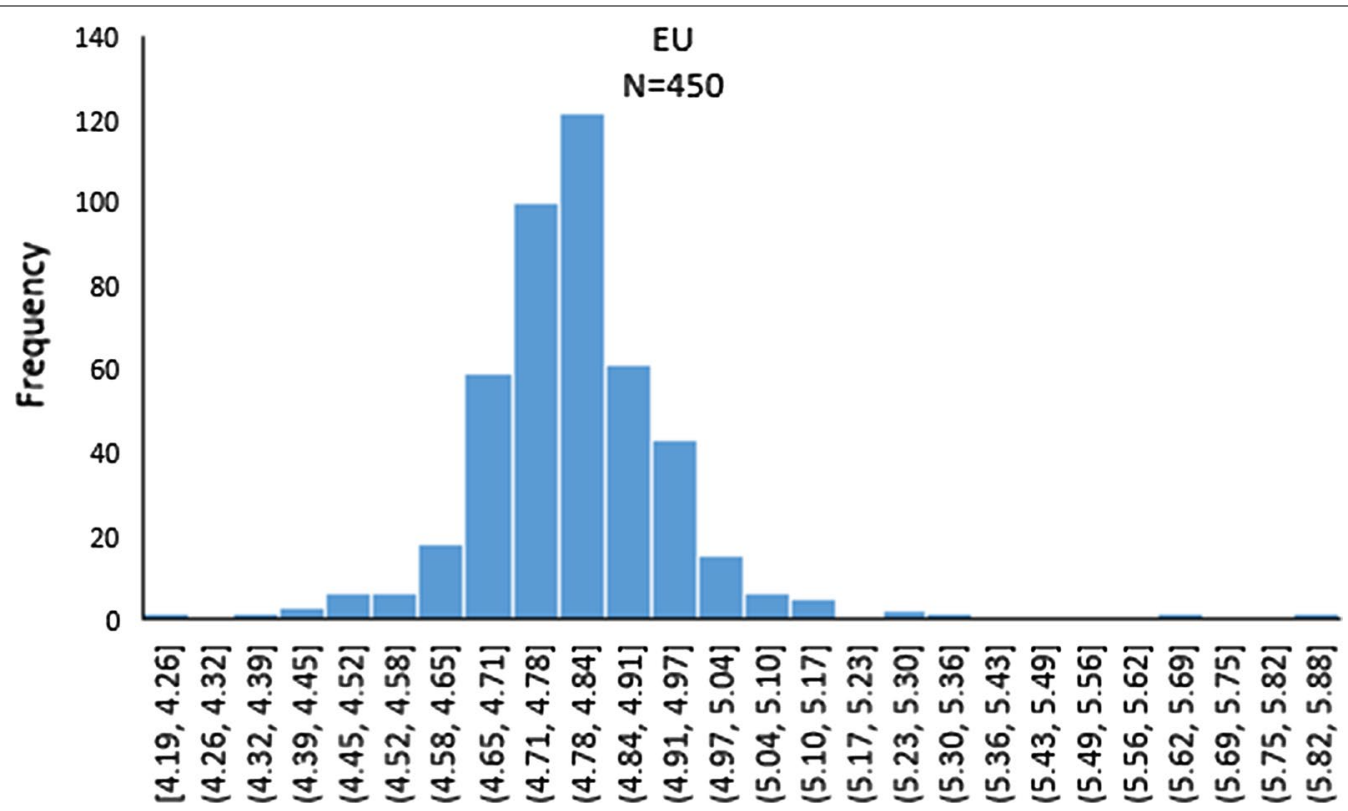

Fig. 3 Frequency distribution of pH for all the studied countries during 2000-2017. The frequency distribution of pH values in case of the studied countries indicates a higher level of acidity, about $94.44 \%$ of the samples having pH values lower than $5,5.11 \%$ between 5 and 5.6 , whilst only $0.44 \%$ of the data fall in the range between 5.6 and 6

In Central East Europe, both the minimum and maximum $\mathrm{pH}$ values were recorded at Belarus, being 4.56 and 5.33, respectively, whilst the frequency distribution showed that $93.26 \%$ of the values are below 5 , and $6.74 \%$ between 5 and 5.6. In case of Northern Europe, the precipitation is more acidic, with $96.67 \%$ of the $\mathrm{pH}$ values being lower than 5 and only $3.33 \%$ ranging between 5 and 5.6. The minimum and maximum values were 4.47 and 5.15 recorded in Estonia and in the United Kingdom, respectively.

The southern region of Europe presented a little less acidic $\mathrm{pH}$ values, that ranged from 4.39 (Serbia) to 5.17 (Spain), having a normal distribution, with the $91.80 \%$ of the values $<5$ and $8.20 \%$ of the values integrating in the $5-5.6$ interval. In the western region, the $95.51 \%$ of the rainwater $\mathrm{pH}$ values had a frequency of $95.51 \%$, whilst the remaining percentage was equally distributed between the 5-5.6 and 5.6-6 intervals, exhibiting $2.25 \%$.

The frequency distribution of predominantly acidic $\mathrm{pH}$ in all the studied countries suggest the significant influence of anthropogenic sources and activities, which correlates with the VWM concentrations of major ions, since such low $\mathrm{pH}$ values explain the higher concentrations of acidic ions in comparison with alkaline ones.

\section{Neutralising capacity and alkalisation of rainwater}

Previous studies have shown that the acidity of rainwater is usually controlled by the presence of $\mathrm{H}_{2} \mathrm{SO}_{4}$, $\mathrm{HNO}_{3}$ and organic acids, whilst the neutralisation of these acidic species occurs mainly in the presence of $\mathrm{NH}_{3}$ and $\mathrm{CaCO}_{3}[10,22]$. Harrison and Pio [26] reported that the abundance of $\mathrm{SO}_{4}{ }^{2-}$ and $\mathrm{NO}_{3}{ }^{-}$is relatively constant with altitude, whilst $\mathrm{NH}_{3}$ and $\mathrm{NH}_{4}{ }^{+}$ions decrease in concentration rapidly with height. According to the above, at cloud level acidic species such as $\mathrm{H}_{2} \mathrm{SO}_{4}, \mathrm{HNO}_{3}$ and $\mathrm{NH}_{4} \mathrm{HSO}_{4}$ are more likely to be in majority over neutralised species like $\left(\mathrm{NH}_{4}\right)_{2} \mathrm{SO}_{4}$ and $\mathrm{NH}_{4} \mathrm{NO}_{3}$ [27]. Hence, at cloud level, the neutralisation process occurs due to the reaction of $\mathrm{Ca}(\mathrm{OH})_{2}$ and $\mathrm{Mg}(\mathrm{OH})_{2}$ with $\mathrm{H}_{2} \mathrm{SO}_{4}$ and $\mathrm{HNO}_{3}$ in the cloud condensation nuclei, whilst below cloud level, neutralisation occurs due to ammonia and the adsorption of $\mathrm{SO}_{2}$ to suspended particulate matter containing $\mathrm{Ca}^{2+}$ and $\mathrm{Mg}^{2+}$ [27]. The concentration of the $\mathrm{H}^{+}$ion reflects the acidity of raindrops after the neutralisation process by $\mathrm{Ca}^{2+}$ and $\mathrm{NH}_{4}^{+}$[28]. According to Kaya and Tuncel [29], if the acidity in rainwater is caused by $\mathrm{H}_{2} \mathrm{SO}_{4}$ and $\mathrm{HNO}_{3}$ and it is not neutralised, then the $\mathrm{H}^{+} /$ $\left(\mathrm{SO}_{4}{ }^{2-}+\mathrm{NO}_{3}{ }^{-}\right)$ratio, referred to as fractional acidity (FA) in numerous studies [27, 30], is expected to be unity. FA has a mean value of 0.31 , ranging between 0.03 and 1.02 , indicating that on average, the $69 \%$ of the inorganic acidity in precipitation is neutralised over Europe. Regarding the studied regions, results were similar to the overall FA values, showing an average of 0.29 in Central East Europe and Northern Europe, 0.30 in Southern Europe and 0.31 in Western Europe, respectively. To further investigate the relationship 
between neutralisation and rainwater acidity, the FA values were plotted against $\mathrm{pH}$ values for Europe and all four regions (Fig. 4).

The results show a positive significant exponential function between FA and $\mathrm{pH}$ for Central East Europe $\left(R^{2}=0.397\right)$, Southern Europe $\left(R^{2}=0.368\right)$, Western Europe $\left(R^{2}=0.8114\right)$ and the European continent $\left(R^{2}=0.4983\right)$, explaining the lower $\mathrm{pH}$ values and showing that the main acidic ions that control the precipitations' acidity are sulphate and nitrate, even if the majority of acidic species are neutralised when entering the atmosphere [24]. The lack of significant correlation in case of Norther Europe can be attributed to the influence of different anthropogenic and/or natural sources on the rainwater's $\mathrm{pH}$ value.

The neutralising effect of crustal components, ammonium and sodium was determined using the neutralisation factors (NFs) [10,31]:

$$
\mathrm{NF}_{\mathrm{xi}}=\frac{\left[X_{\mathrm{i}}\right]}{\left[\mathrm{SO}_{4}^{2-}\right]+\left[\mathrm{NO}_{3}^{-}\right]},
$$

where $\left[X_{\mathrm{i}}\right]$ is the concentration of the alkaline component $\left(\mathrm{Ca}^{2+}, \mathrm{NH}_{4}^{+}, \mathrm{Mg}^{2+}, \mathrm{Na}^{+}, \mathrm{K}^{+}\right)$. Multiannual mean values of NFs for each country are presented in Fig. 5 . The overall results showed that $\mathrm{Na}^{+}$has the highest neutralising capacity, with an average value of 0.54 , ranging between 0.04 and 0.98 , being followed by $\mathrm{NH}_{4}{ }^{+}$that ranged from 0.03 to 1.25 , exhibiting a mean value of 0.46 . The other cations, such as $\mathrm{Ca}^{2+}, \mathrm{Mg}^{2+}$ and $\mathrm{K}^{+}$, did not play such an important role in neutralising the rainwater acidity. In general, values were lower than unity, showing the significant influence of acidic species over the neutralising ones.
Although according to the above-mentioned methods, the neutralisation of rainwater acidity occurs, it is important to note that the neutralising potential (NP) of precipitation is not as dominant as the acidic potential (AP). The acidic potential is the sum of the concentrations of non-sea salt (nss) $\mathrm{SO}_{4}{ }^{2-}$ and $\mathrm{NO}_{3}{ }^{-}$, whilst the neutralisation potential is the sum of the concentrations of nns$\mathrm{Ca}^{2+}$, nss- $\mathrm{Mg}^{2+}$, nss- $\mathrm{K}^{+}$and $\mathrm{NH}_{4}{ }^{+}[32,33]$. The AP/NP ratio was determined for all the studied countries, showing in average higher values than 1 , having a minimum value of 1.24 in Portugal and a maximum value of 2.18 in Turkey, explaining the percentage distribution of rainwater $\mathrm{pH}$, that ranges between 5 and 5.6, showing a predominantly acidic character.

To further examine the relationship between acidic species and neutralising compounds, and to understand the relative contributions of sulphuric and nitric acid to the total acidity of rainwater [25,28], ionic ratios such as $\left(\mathrm{NO}_{3}{ }^{-}+\mathrm{Cl}^{-}\right) / \mathrm{SO}_{4}{ }^{2-}, \mathrm{SO}_{4}{ }^{2-} / \mathrm{NO}_{3}{ }^{-}, \mathrm{NH}_{4}{ }^{+} / \mathrm{NO}_{3}{ }^{-}$, $\mathrm{NH}_{4}{ }^{+} / \mathrm{SO}_{4}{ }^{2-}, \quad\left(\mathrm{Ca}^{2+}+\mathrm{Mg}^{2+}+\mathrm{NH}_{4}{ }^{+}\right) /\left(\mathrm{NO}_{3}{ }^{-}+\mathrm{SO}_{4}{ }^{2-}\right)$ and $\left(\mathrm{NO}_{3}{ }^{-}+\mathrm{SO}_{4}{ }^{2-}\right) /\left(\mathrm{Ca}^{2+}+\mathrm{Mg}^{2+}\right)$ were calculated. In Europe, the average $\left(\mathrm{NO}_{3}{ }^{-}+\mathrm{Cl}^{-}\right) / \mathrm{SO}_{4}{ }^{2-}$ ratio was 1.31, ranging from 0.87 (Estonia) to 9.72 (Turkey), exhibiting in average at all countries higher ratios than unity. These results indicate that nitric and hydrochloric acid had a significant contribution to the acidity of precipitation, whereas a ratio below one shows the influence of sulphuric acid [34]. The average ratios of $\mathrm{SO}_{4}{ }^{2-}$ / $\mathrm{NO}_{3}{ }^{-}$ranged from 1.78 (Portugal) to 2.83 (Serbia) having a mean value of 1.96 , showing that sulphuric acid had a more substantial effect on the acidity of rainwater than nitric acid. Analysing the concentrations of $\mathrm{NH}_{4}{ }^{+}$ reported to the concentrations of $\mathrm{NO}_{3}{ }^{-}$, it can be said that ammonium neutralises nitrous species, since this

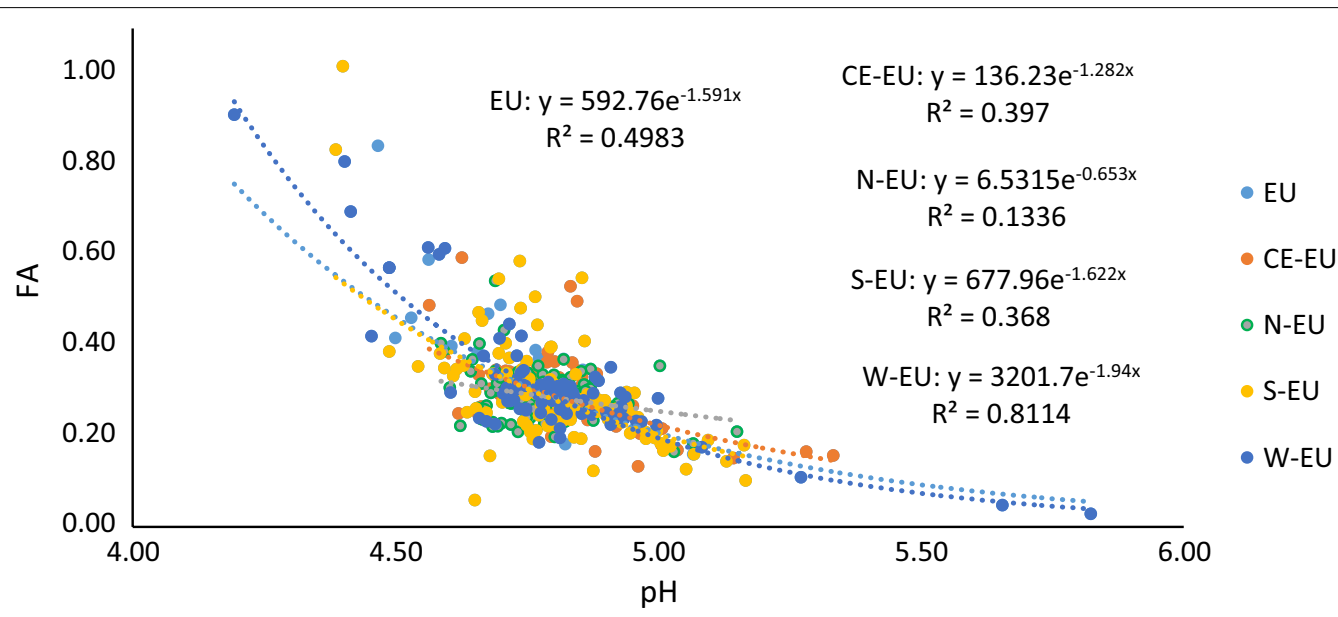

Fig. 4 Relationship between $\mathrm{FA}$ and $\mathrm{pH}$ in rainwater samples over Europe and the studied regions. Linear regression analysis between $\mathrm{FA}$ and $\mathrm{pH}$ values showed a positive significant exponential function for the European continent and its regions, respectively 


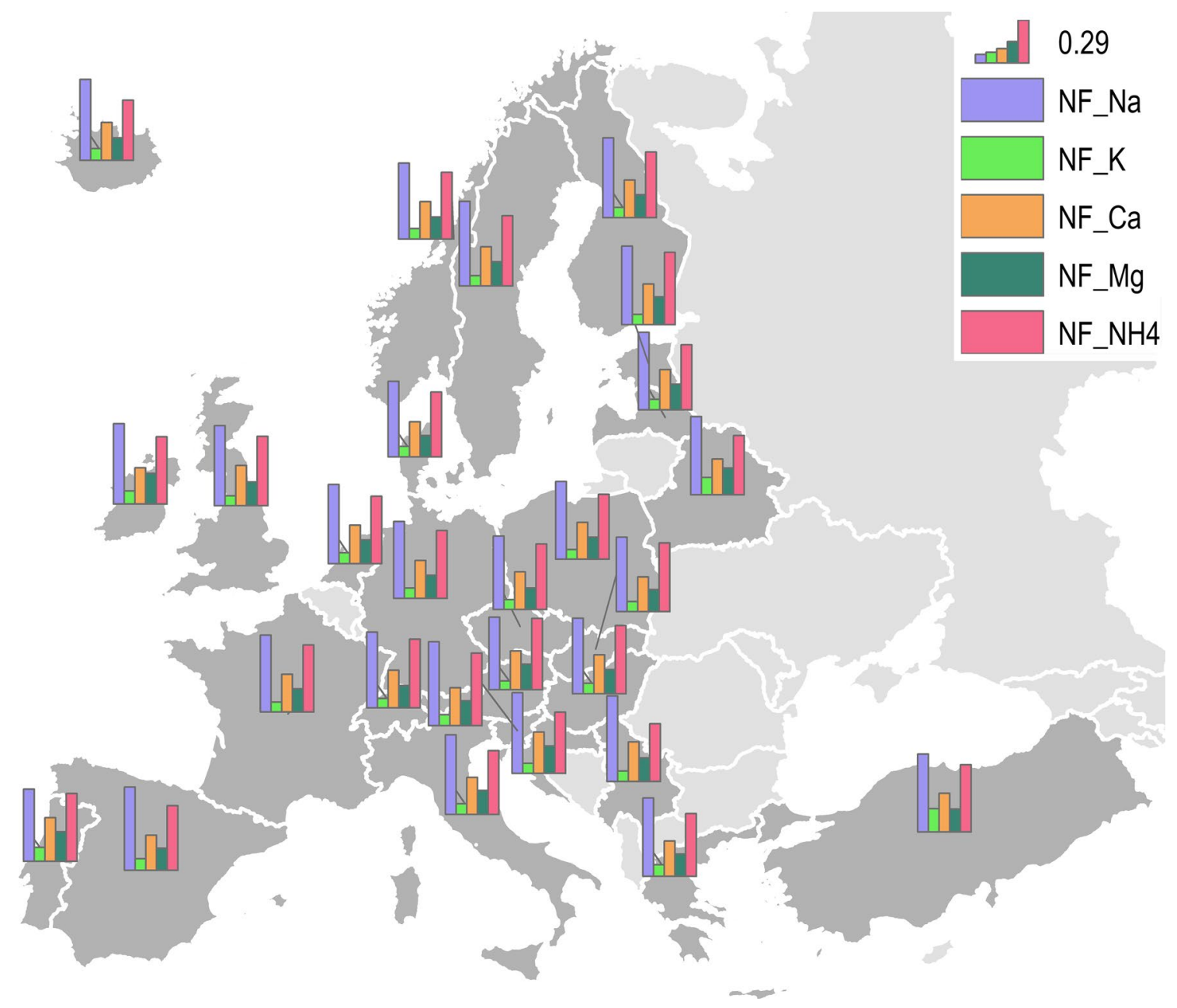

Fig. 5 Neutralisation factors of major alkaline ions and the AP/NP ratio in precipitation. Multiannual mean values of NFs and AP/NP ratios for each country are presented. Results showed that $\mathrm{Na}^{+}$has the highest neutralising capacity, whilst the AP/NP ratio exhibited in average higher values than 1, explaining the acidic character of the rainwater over the European continent

ratio exhibited higher values than unity (avg. 1.12), possibly forming $\mathrm{NH}_{4} \mathrm{NO}_{3}$ in the atmosphere [35]. The $\mathrm{NH}_{4}{ }^{+} / \mathrm{SO}_{4}{ }^{2-}$ ratio can be used to indicate the relationship between different ions in the atmosphere. According to [36], if this ratio is lower than unity sulphates such as $\mathrm{CaSO}_{4}$ and $\left(\mathrm{NH}_{4}\right)_{2} \mathrm{SO}_{4} \cdot \mathrm{CaSO}_{4} \cdot 2 \mathrm{H}_{2} \mathrm{O}$ are formed, if the molar ratio of $\mathrm{NH}_{4}{ }^{+} / \mathrm{SO}_{4}{ }^{2-}$ is closer to one, it means that both $\mathrm{NH}_{4} \mathrm{HSO}_{4}$ and $\left(\mathrm{NH}_{4}\right)_{2} \mathrm{SO}_{4}$ are present in the atmosphere. For Europe, the results showed a ratio that ranged between 0.50 (Serbia) and 0.64 (Turkey), with an average value of 0.58 , meaning that sulphates such as $\mathrm{CaSO}_{4}$ and $\left(\mathrm{NH}_{4}\right)_{2} \mathrm{SO}_{4} \cdot \mathrm{CaSO}_{4} \cdot 2 \mathrm{H}_{2} \mathrm{O}$ are often formed the atmosphere. The average ratio of $\left(\mathrm{Ca}^{2+}+\mathrm{Mg}^{2+}+\mathrm{NH}_{4}^{+}\right) /\left(\mathrm{NO}_{3}{ }^{-}+\mathrm{SO}_{4}{ }^{2-}\right)$ is 0.73 , which is below one, and the average ratio of $\left(\mathrm{NO}_{3}{ }^{-}+\mathrm{SO}_{4}{ }^{2-}\right) /$ $\left(\mathrm{Ca}^{2+}+\mathrm{Mg}^{2+}\right)$ that exhibited a mean value of 2.94 indicate the acidic nature of rainwater and the significant influence of $\mathrm{NO}_{3}{ }^{-}$and $\mathrm{SO}_{4}{ }^{2-}$ compounds in the atmosphere over Europe.

To assess the availability of ammonia for neutralisation of acidic species $\left(\mathrm{H}_{2} \mathrm{SO}_{4}, \mathrm{HNO}_{3}\right)$ in the atmosphere, the ammonium availability index (AAI) was determined. AAI is expressed by the molar ratio of the ammonium concentration to the amount needed to fully neutralise sulphuric and nitric acids [37, 38]:

$$
\mathrm{AAI}=\frac{\left[\mathrm{NH}_{4}^{+}\right]}{2 \times\left[\mathrm{SO}_{4}^{2-}\right]+\left[\mathrm{NO}_{3}^{-}\right]} \times 100 \% .
$$

If $\mathrm{AAI}<100 \%$, there is an ammonium deficit, suggesting that sulphate and nitrate are acidic; if $\mathrm{AAI}=100 \%$, then the precise neutralisation of sulphate and nitrate occurs, whilst if the value of AAI exceeds $100 \%$, then there is sufficient 
ammonium to fully neutralise sulphuric and nitric acids. In general, significant differences between the studied regions were not observed; the mean value of AAI during the studied period for Europe was $22.86 \%$, with values ranging between 3.07\% (Turkey) and 60.02\% (Slovenia), indicating that there is no enough ammonium present to fully neutralise sulphuric and nitric acids. AAI is only an indicator of the neutralising capacity of $\mathrm{NH}_{4}{ }^{+}$over sulphuric and nitric acids and its value did not correspond to the $\mathrm{pH}$ value of the rainwater, since there are other neutralising compounds such as calcium, magnesium or sodium, that could contribute to the $\mathrm{pH}$ value of precipitation [37].

\section{Wet deposition rates of major ions}

Wet deposition is an important pathway of pollutant removal from the atmosphere, giving further insights on the chemical composition of precipitation and providing information on long-range transported pollutants. The multiannual wet deposition (WD) fluxes for all studied regions were estimated according to the following equation [21]:

$$
\mathrm{WD}\left(\mathrm{kg} \mathrm{ha}^{-1} \text { year }^{-1}\right)=\operatorname{VWM}\left(\mathrm{mg} \mathrm{L}^{-1}\right) \times \frac{\mathrm{RF}}{100}
$$

where WD is expressed in $\mathrm{kg} \mathrm{ha}^{-1}$ year $^{-1}$, VWM is the volume-weighted mean expressed in $\mathrm{mg} \mathrm{L}^{-1}$, whilst $R F$ is the annual rainfall amount.

The multiannual wet deposition fluxes for the 20002017 period for Europe are displayed in Fig. 6, varying from site to site due to different rainwater amounts. Regarding at the results, large differences in the annual deposition rates of anions to cations were obtained. The highest deposition fluxes were obtained for sulphate, with the exception of Turkey, where nitrate had higher deposition rates. The average $\mathrm{SO}_{4}^{2-}$ for Europe

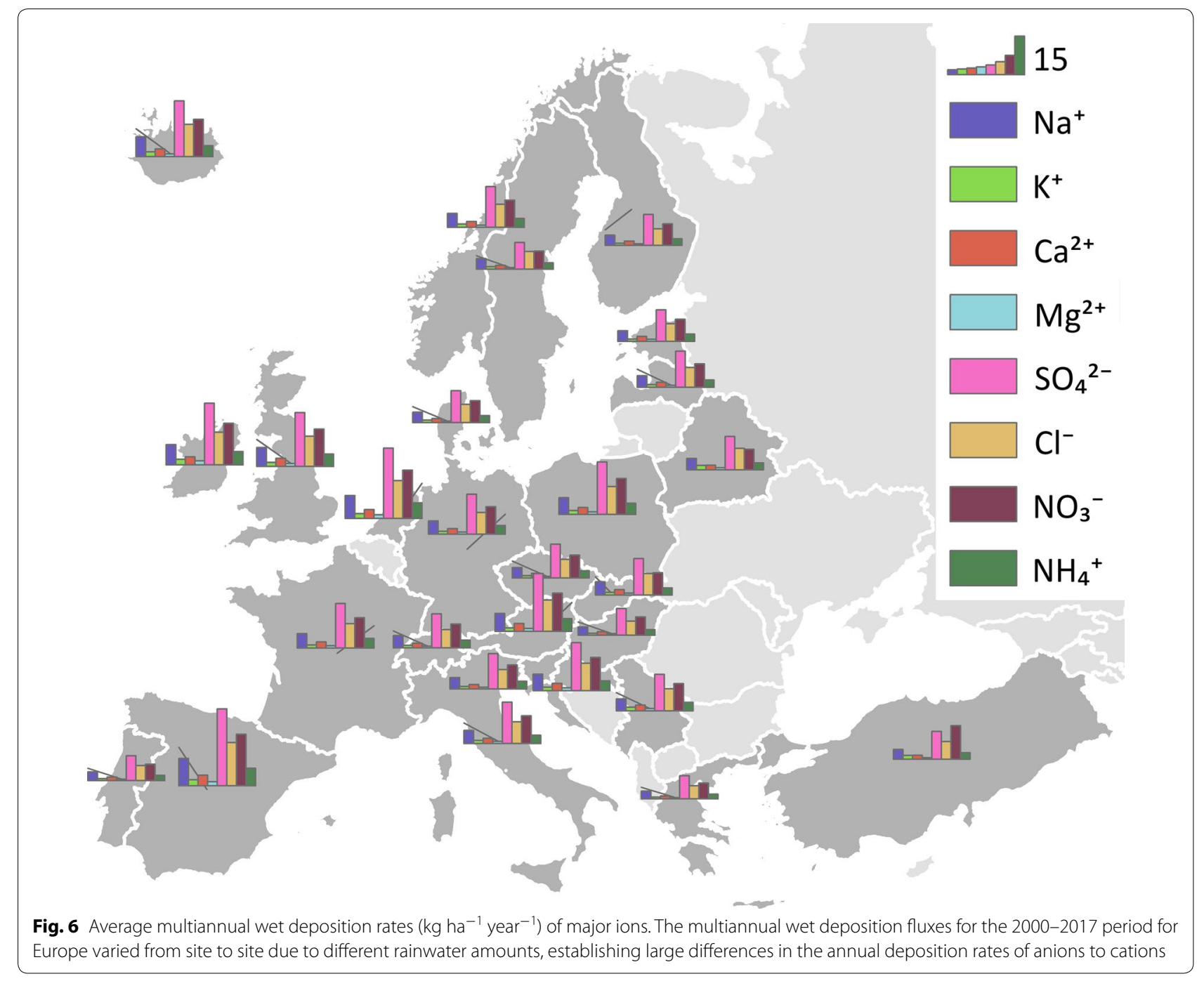


was $15.88 \mathrm{~kg} \mathrm{ha}^{-1}$ year $^{-1}$, ranging between $8.87 \mathrm{~kg} \mathrm{ha}^{-1}$ year $^{-1}$ (Greece) and $29.64 \mathrm{~kg} \mathrm{ha}^{-1}$ year $^{-1}$ (Slovenia). The total quantity of sulphate deposited on the surface of the studied European countries was $428.86 \mathrm{~kg} \mathrm{ha}^{-1}$ year $^{-1}$. Nitrate and chloride also presented high WD values, with an average of $10.96 \mathrm{~kg} \mathrm{ha}^{-1}$ year $^{-1}\left(\min .6 .05 \mathrm{~kg} \mathrm{ha}^{-1}\right.$ year $^{-1}$ - Greece; max. $20.14 \mathrm{~kg} \mathrm{ha}^{-1}$ year $^{-1}$-Slovenia) and $8.93 \mathrm{~kg} \mathrm{ha}^{-1}$ year $^{-1}$ (min. $5.05 \mathrm{~kg} \mathrm{ha}^{-1}$ year ${ }^{-1}$-Greece; max. $16.66 \mathrm{~kg} \mathrm{ha}^{-1}$ year $^{-1}$-Slovenia), respectively.

Regarding the results, it can be said that in case of acidic species, the lowest depositions can be found in Greece, whilst the highest in Slovenia. This is probably due to the Mediterranean climate in Greece, with less amounts of precipitation versus the moderate continental climate of Slovenia, with abundant precipitation in the western part of the country. The good pollutant dispersion conditions, mainly in the insular regions of Greece, may also be a cause for lower deposition rates, whereas in Slovenia the effect of continental pollutant accumulation can be felt more intensely. In case of cations, the maximum WD fluxes were estimated for sodium $\left(10.55 \mathrm{~kg} \mathrm{ha}^{-1}\right.$ year $^{-1}$ ) and ammonium $\left(6.78 \mathrm{~kg} \mathrm{ha}^{-1}\right.$ year $\left.^{-1}\right)$, both being registered in Slovenia. The average deposition fluxes for $\mathrm{Na}^{+}$and $\mathrm{NH}_{4}{ }^{+}$were 5.32 and $3.43 \mathrm{~kg} \mathrm{ha}^{-1}$ year $^{-1}$, whilst the total amount of WD in case of these cations was 143.71 and $92.57 \mathrm{~kg} \mathrm{ha}^{-1}$ year $^{-1}$, respectively. Overall, these results correlate with the values of $\mathrm{pH}$, neutralisation factors, ionic ratios and the ammonium availability indexes, explaining the greater concentration of acidic compounds in precipitation, that may be caused by the anthropogenic and industrial activities, coal combustion and traffic.

\section{Origins of major ions in precipitation Marine and crustal enrichment factors}

The chemical composition of rainwater is mainly influenced by anthropogenic sources, sea spray, volcanic activity, biogenic material and terrestrial dust from weathering $[9,39,40]$.

Marine and crustal enrichment factors (EFs) were applied to identify and examine the sources and contributions of major ions in rainwater [41, 42]. Enrichment factors are based on the elemental ratio found between ions measured in rainwater compared to a similar ratio for a reference material [40]. In general, $\mathrm{Na}^{+}$is used as a reference element for seawater, since it is assumed to be originating only from marine sources [21, 43], whilst to characterise the ions deriving from the continental crust $\mathrm{Ca}^{2+}$ can be used as the reference ion [44]. Marine and crustal EFs can be expressed as

$$
\mathrm{EF}_{\text {seawater }}=\left[\mathrm{X} / \mathrm{Na}^{+}\right]_{\text {rainwater }} /\left[\mathrm{X} / \mathrm{Na}^{+}\right]_{\text {seawater }},
$$

$$
\mathrm{EF}_{\text {crust }}=\left[\mathrm{X} / \mathrm{Ca}^{2+}\right]_{\text {rainwater }} /\left[\mathrm{X} / \mathrm{Ca}^{2+}\right]_{\text {crust }},
$$

where $\mathrm{X}$ is the concentration of the element of interest in rainwater, $\mathrm{X} / \mathrm{Na}^{+}$and $\mathrm{X} / \mathrm{Ca}^{2+}$ of rainwater represent the ratio from rainwater composition, whilst $\mathrm{X} / \mathrm{Na}^{+}$seawater and $\mathrm{X} / \mathrm{Ca}^{2+}$ crust are the ratio of seawater and crustal composition, respectively $[2,45]$.

The mean values of marine and crustal enrichment factors are shown in Table 1. An element is considered to be enriched or diluted relative to the reference source if the EF value is much higher or much smaller than unity, respectively [10, 30, 39]. The values of marine EFs for $\mathrm{Cl}^{-}$ranged between 0.86 in Sweden and 1.29 in Austria, whilst the $\mathrm{EF}_{\text {Crust }}$ values for the same element ranged from 682.75 (Portugal) to 1090.18 (Belarus). These results suggest that $\mathrm{Cl}^{-}$has marine origins, since the $\mathrm{EF}_{\text {Marine }}$ values are close to the seawater reference ratio (1.16), whilst the EF values for continental crust are much higher than one, indicating a significant enrichment.

Both $\mathrm{EF}_{\text {Marine }}$ and $\mathrm{EF}_{\text {Crust }}$ values have shown that $\mathrm{K}^{+}$ is mainly derived from terrestrial sources, since EFs are enriched compared to seawater and slightly diluted or exhibiting values that are close to the $\mathrm{K}^{+} / \mathrm{Ca}^{2+}(0.504)$ reference crustal ratio. Regarding crustal enrichment factors for $\mathrm{K}^{+}$, in average values ranged between 0.46 (Austria) and 0.71 (Ireland), excepting Belarus (1.13) and Turkey (1.24), where EF values greater than one are suggesting the influence of other sources too, since fine particulate potassium is a result of biomass combustion [9] and also can be found in some types of chemical fertilisers [46]. EF ratios for $\mathrm{Mg}^{2+} / \mathrm{Ca}^{2+}$ are ranging between 1.03 (Czech Republic) and 1.58 (Belarus), showing a slight enrichment relative to the reference $\mathrm{Mg}^{2+} / \mathrm{Ca}^{2+}$ (0.561) ratio. This suggests that a small fraction of $\mathrm{Mg}^{2+}$ ions in rainwater may originate from sources other than terrestrial, such as marine. $\mathrm{EF}$ seawater values for $\mathrm{Ca}^{2+}$ showed crustal origins, from soil-derived components and terrestrial dust or limestone/dolomite weathering [30]. As expected, both marine and crustal EF values for $\mathrm{SO}_{4}{ }^{2-}$ are present in highly enriched form, showing the significant influence of anthropogenic activities and the minimal contribution from soil dust and sea salts $[39,44]$.

\section{Sea salt and non-sea salt contributions}

To estimate the marine and non-marine contribution of different ionic species in precipitation, sea salt fractions (SSF) and non-sea salt fractions (NSSF) were calculated, using $\mathrm{Cl}^{-}$as a reference element. Since in most of the rains, the $\mathrm{Na}^{+} / \mathrm{Cl}^{-}$ratio showed approximate results with the $\mathrm{Na}^{+} / \mathrm{Cl}^{-}$marine ratio (0.86), the use of chloride as a sea salt tracer was found valid [47]. The contributions of sea salt fractions (SSF) and non-sea salt fractions (NSSF) 
Table 1 Enrichment factors for sea salt and soil components relative to rainwater

\begin{tabular}{|c|c|c|c|c|c|c|c|c|c|c|}
\hline & $\mathrm{EF}_{\text {sea }}$ & & & & & $\mathrm{EF}_{\text {crust }}$ & & & & \\
\hline & $\frac{\mathrm{Cl}^{-}}{\mathrm{Na}^{+}}$ & $\frac{\mathrm{K}^{+}}{\mathrm{Na}^{+}}$ & $\frac{\mathrm{Ca}^{2+}}{\mathrm{Na}^{+}}$ & $\frac{\mathrm{Mg}^{2+}}{\mathrm{Na}^{+}}$ & $\frac{\mathrm{SO}_{4}^{2-}}{\mathrm{Na}^{+}}$ & $\frac{\mathrm{Cl}^{-}}{\mathrm{Ca}^{2+}}$ & $\frac{\mathrm{K}^{+}}{\mathrm{Ca}^{2+}}$ & $\frac{\mathrm{Na}^{+}}{\mathrm{Ca}^{2+}}$ & $\frac{\mathrm{Mg}^{2+}}{\mathrm{Ca}^{2+}}$ & $\frac{\mathrm{SO}_{4}^{2-}}{\mathrm{Ca}^{2+}}$ \\
\hline Austria & 1.29 & 5.79 & 14.85 & 1.77 & 18.06 & 738.01 & 0.46 & 3.33 & 1.23 & 172.22 \\
\hline Belarus & 1.11 & 10.81 & 11.54 & 1.55 & 11.68 & 1090.18 & 1.13 & 4.84 & 1.58 & 199.88 \\
\hline Croatia & 1.02 & 5.87 & 12.17 & 1.51 & 11.67 & 722.55 & 0.50 & 3.52 & 1.20 & 148.49 \\
\hline Czech Rep. & 1.04 & 6.25 & 12.12 & 1.33 & 13.66 & 764.52 & 0.53 & 3.52 & 1.03 & 170.94 \\
\hline Denmark & 1.08 & 6.66 & 11.06 & 1.33 & 13.49 & 858.23 & 0.62 & 3.87 & 1.12 & 183.65 \\
\hline Estonia & 0.94 & 6.09 & 12.17 & 1.66 & 12.07 & 741.85 & 0.55 & 3.73 & 1.37 & 162.47 \\
\hline Finland & 0.91 & 5.86 & 11.20 & 1.29 & 12.11 & 727.14 & 0.54 & 3.78 & 1.08 & 164.61 \\
\hline France & 0.95 & 5.93 & 11.62 & 1.37 & 12.48 & 740.59 & 0.53 & 3.69 & 1.11 & 164.43 \\
\hline Germany & 0.93 & 6.13 & 11.64 & 1.37 & 12.52 & 716.60 & 0.54 & 3.64 & 1.10 & 163.60 \\
\hline Greece & 1.00 & 7.33 & 11.14 & 1.34 & 14.20 & 802.12 & 0.66 & 3.98 & 1.13 & 190.45 \\
\hline Hungary & 0.94 & 6.40 & 12.00 & 1.45 & 13.02 & 714.80 & 0.55 & 3.55 & 1.17 & 167.17 \\
\hline Iceland & 0.90 & 6.56 & 11.33 & 1.27 & 12.05 & 754.74 & 0.64 & 3.92 & 1.08 & 162.83 \\
\hline Ireland & 0.91 & 7.65 & 10.57 & 1.75 & 12.08 & 769.16 & 0.71 & 3.98 & 1.50 & 174.15 \\
\hline Italy & 0.94 & 6.35 & 11.41 & 1.40 & 12.44 & 778.61 & 0.61 & 4.01 & 1.19 & 175.54 \\
\hline Latvia & 0.96 & 6.32 & 12.34 & 1.53 & 12.74 & 716.91 & 0.54 & 3.55 & 1.14 & 160.32 \\
\hline Norway & 0.94 & 6.53 & 11.74 & 1.32 & 12.88 & 726.41 & 0.58 & 3.65 & 1.07 & 167.90 \\
\hline Poland & 0.95 & 5.75 & 11.01 & 1.27 & 11.96 & 763.16 & 0.53 & 3.76 & 1.08 & 164.90 \\
\hline Portugal & 0.99 & 9.04 & 14.26 & 1.89 & 12.58 & 682.75 & 0.67 & 3.23 & 1.27 & 144.30 \\
\hline Serbia & 0.94 & 5.68 & 10.88 & 1.25 & 11.13 & 784.42 & 0.54 & 3.92 & 1.09 & 157.94 \\
\hline Slovakia & 0.97 & 6.27 & 11.05 & 1.35 & 13.02 & 797.72 & 0.59 & 3.88 & 1.15 & 180.18 \\
\hline Slovenia & 0.88 & 6.03 & 10.73 & 1.33 & 11.43 & 747.90 & 0.58 & 4.00 & 1.17 & 161.96 \\
\hline Spain & 1.01 & 6.67 & 10.25 & 1.23 & 10.69 & 853.01 & 0.66 & 4.18 & 1.12 & 157.65 \\
\hline Sweden & 0.86 & 5.81 & 12.59 & 1.42 & 12.96 & 714.06 & 0.55 & 4.03 & 1.15 & 165.51 \\
\hline Switzerland & 0.94 & 5.82 & 11.81 & 1.33 & 12.90 & 711.91 & 0.51 & 3.59 & 1.06 & 166.21 \\
\hline Netherlands & 0.92 & 6.37 & 11.32 & 1.34 & 11.96 & 727.58 & 0.57 & 3.70 & 1.10 & 161.74 \\
\hline Turkey & 0.99 & 13.55 & 12.02 & 1.50 & 11.72 & 773.77 & 1.24 & 3.70 & 1.18 & 151.19 \\
\hline UK & 0.91 & 5.69 & 11.87 & 1.33 & 12.00 & 715.31 & 0.51 & 3.68 & 1.08 & 155.88 \\
\hline
\end{tabular}

Marine and crustal enrichment factors (EFs) were applied to identify and examine the sources and contributions of major ions in rainwater

can be defined by comparing the $\mathrm{Na}^{+} / \mathrm{Cl}^{-}$ratio in rainwater to that of seawater, using the following equations:

$$
\% \mathrm{SSF}=\frac{100 *(\mathrm{Cl})_{\text {rain }} *(X / \mathrm{Cl})_{\text {sea }}}{(\mathrm{X})_{\text {rain }}}
$$

$$
\% \mathrm{NSSF}=100-\mathrm{SSF},
$$

where $X$ is the concentration of the respective ion.

Results presented in Fig. 7 are in concordance with that found in case of enrichment factors, suggesting that $\mathrm{Ca}^{2+}, \mathrm{K}^{+}$and $\mathrm{SO}_{4}^{2-}$ appear to be of non-marine origin over the studied countries, whilst $\mathrm{Mg}^{2+}$ beside crustal origin can also be attributed to sea salt influences. In average, over the studied countries, $91.42 \% \mathrm{Ca}^{2+}, 85.60 \%$ $\mathrm{K}^{+}$and $92.13 \% \mathrm{SO}_{4}^{2-}$ in precipitation came from non-sea salt sources. The high percentage of nss- $\mathrm{SO}_{4}^{2-}$ shows the influence of rapid industrialisation, which comes along with considerable energy consumption, such as coal combustion and $\mathrm{SO}_{2}$ emission by thermal power plants [10]. Almost all of $\mathrm{Ca}^{2+}$ in all the studied countries can not only be attributed to terrestrial sources, namely the dissolution of dolomites and limestone [21, 40], the remote transport of soil dust from arid and semi-arid areas, which contains large amounts of $\mathrm{Ca}^{2+}[10]$, but also be attributed to anthropogenic activities too, such as quarries or cement factories [5]. Potassium can have various non-marine sources, since it can be found as coarse particles in soil, whilst fine particulate $\mathrm{K}^{+}$from biomass burning and agricultural activities can be present in the atmosphere $[9,30]$. As found in some previous studies, $\mathrm{Mg}^{2+}$ can be attributed to marine sources too. Furthermore, Xiao et al. [48] found that in some remote ocean areas, magnesium had higher concentrations than calcium, which explains the average of $70.43 \%$ of $\mathrm{Mg}^{2+}$ that can be attributed to sea salts, and only $29.57 \%$ to other sources. $\mathrm{Cl}^{-}$in rainwater at all sampling sites mainly 


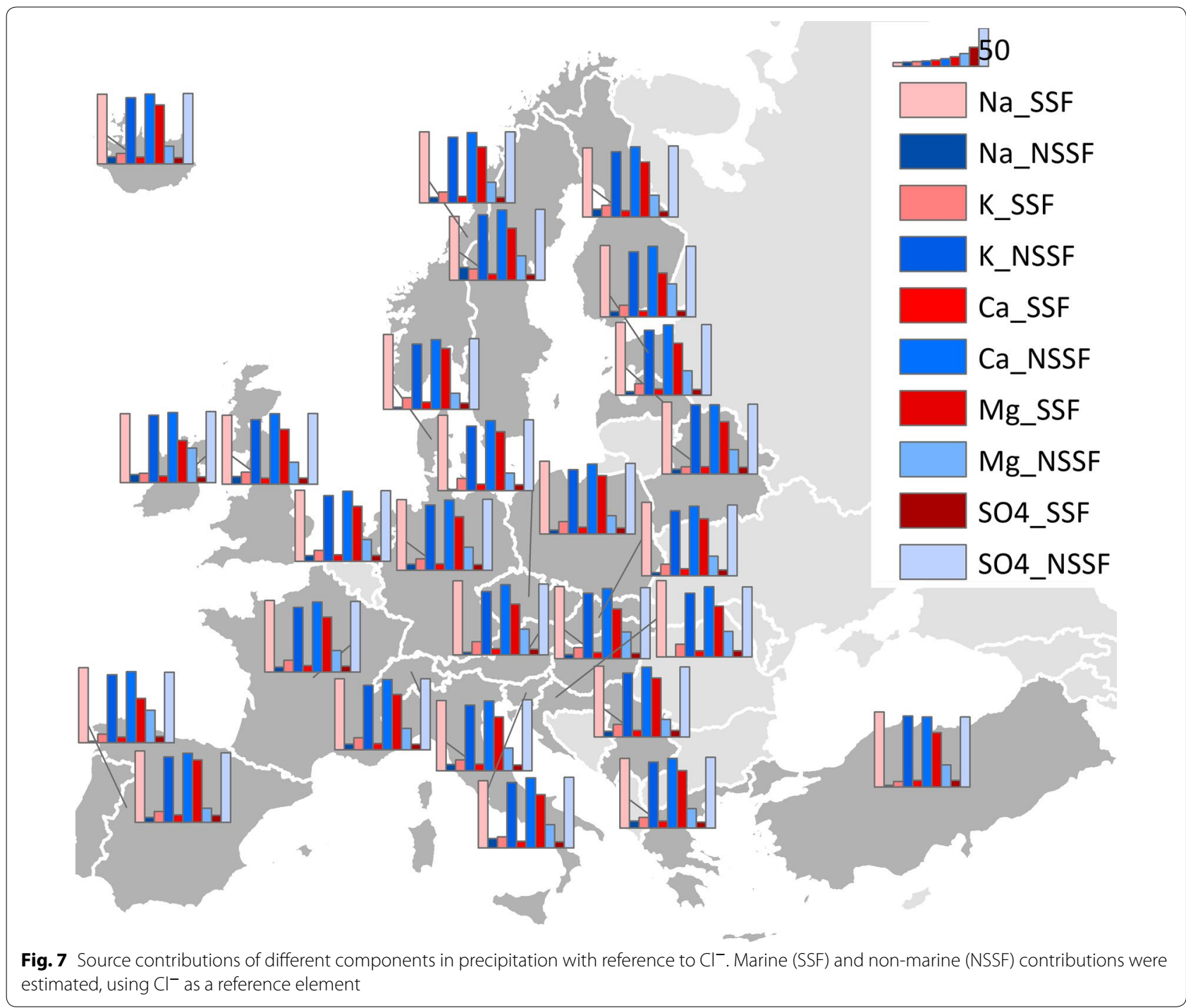

originated from sea salt, having an average SSF value of 93.26\%, ranging between $83.22 \%$ (Sweden) and 99.63\% (Croatia). The non-sea salt fraction of $\mathrm{Cl}^{-}$from rainwater can be attributed to various anthropogenic activities, such as automobile exhaust [49] or iron and steel production [50].

\section{Spearman's rank correlation analysis}

To determine the origin of major anions and cations in rainwater collected at the studied regions, and to apportion the sources and potential linkages, the Spearman rank correlation analysis was performed for each country and for the entire database, considering a correlation significant, if $R>0.50$ at $95 \%$ confidence level (Fig. 8).

$\mathrm{SO}_{4}^{2-}$ and $\mathrm{NO}_{3}^{-}$are significantly correlated $(R=0.72$ for the entire database), showing the similarity of their chemical behaviour in precipitation, as well as the common source (fossil fuel combustion, industrial activities) [10] and co-emission of their precursors $\left(\mathrm{SO}_{2}\right.$ and $\left.\mathrm{NO}_{x}\right)$ [44]. Regarding the correlations between these ions over each studied region, the coefficients were $0.75,0.70,0.70$ and 0.67 for Northern Europe, Western Europe, Southern Europe and Central East Europe, respectively. Similarly, significant correlation values were found between $\mathrm{SO}_{4}^{2-}$ and $\mathrm{Cl}^{-}(R=0.62)$ for all countries, $R$ exhibiting the same value in Northern Europe, 0.66 in Western Europe, 0.56 in Southern Europe and 0.63 in Central East Europe. The $\mathrm{SO}_{4}^{2-}, \mathrm{Cl}^{-}$pair exhibited higher correlation values in the regions where the contribution of NSS chloride was higher, which indicates anthropogenic origin, such as the metallurgic industry, known for coal combustion and use of $\mathrm{Cl}^{-}$[50]. The coexistence of $\mathrm{Ca}^{2+}$ and $\mathrm{Mg}^{2+}, \mathrm{Ca}^{2+}$ and $\mathrm{Na}^{+}, \mathrm{Mg}^{2+}$ and $\mathrm{K}^{+}$, and $\mathrm{Na}^{+}$and $\mathrm{K}^{+}$was observed, indicating the common terrestrial origin in soil and dust. 


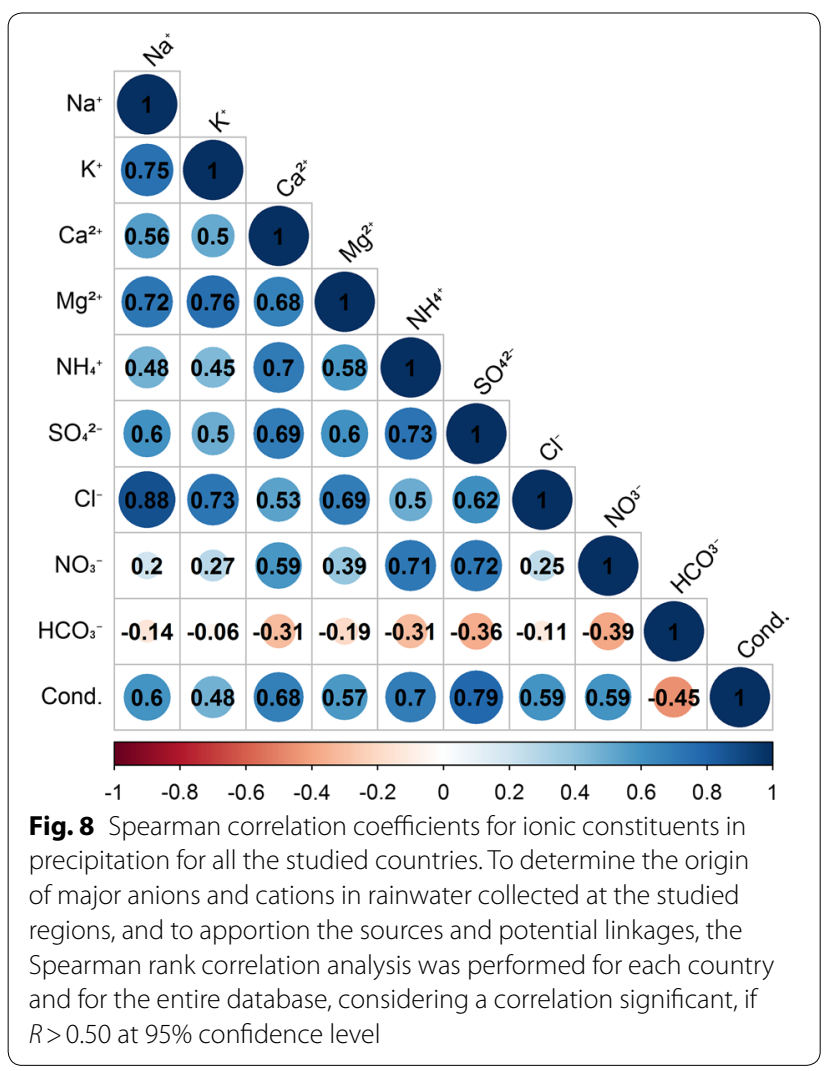

The significant correlations between $\mathrm{Ca}^{2+}$ and $\mathrm{Mg}^{2+}$ ( $R=0.65)$ for the entire database, as well as for all four regions (0.65-Northern Europe, 0.69-Western Europe, 0.75-Southern Europe and 0.59-Central East Europe) imply the presence of calcite, dolomite and limestone in the studied areas, and also being an indicator of quarries or cement factories [30, 51-53]. Good correlation coefficients between $\mathrm{Na}^{+}$and $\mathrm{K}^{+}(0.75-$ Europe and Northern Europe, 0.84-Western Europe, 0.64-Southern Europe, 0.68-Central East Europe) are an indicator of alkali feldspars [30]. The $\mathrm{Ca}^{2+}, \mathrm{Na}^{+}$and $\mathrm{Mg}^{2+}, \mathrm{K}^{+}$pairs are usually found in silicates; therefore, the significant positive correlation coefficients between $\mathrm{Ca}^{2+}, \mathrm{Na}^{+}(R=0.56)$ and $\mathrm{Mg}^{2+}, \mathrm{K}^{+}(R=0.76)$ are an indicator of the variety of igneous, metamorphic and sedimentary rocks in the studied regions. The very good correlation coefficients between $\mathrm{Ca}^{2+}$ and $\mathrm{SO}_{4}^{2-}(R=0.69), \mathrm{Ca}^{2+}$ and $\mathrm{Cl}^{-}(R=0.53), \mathrm{Ca}^{2+}$ and $\mathrm{NO}_{3}^{-}(R=0.59), \mathrm{Mg}^{2+}$ and $\mathrm{SO}_{4}^{2-}(R=0.60), \mathrm{Mg}^{2+}$ and $\mathrm{Cl}^{-}(R=0.69)$ are an indicator of the neutralising capacity of cations over acidic compounds, and according to Lu et al. [44] are probably the result from the reaction of alkaline species rich in $\mathrm{Ca}^{2+}$ and $\mathrm{Mg}^{2+}$ with $\mathrm{H}_{2} \mathrm{SO}_{4}$, $\mathrm{HNO}_{3}$ and $\mathrm{HCl}$ acids. In the atmosphere, ammonia is usually present in the form of $\left(\mathrm{NH}_{4}\right)_{2} \mathrm{SO}_{4}, \mathrm{NH}_{4} \mathrm{HSO}_{4}$ and $\mathrm{NH}_{4} \mathrm{NO}_{3}$, being the product of its reaction with $\mathrm{H}_{2} \mathrm{SO}_{4}$ and $\mathrm{HNO}_{3}$ [9]. Since the correlation coefficient of $\mathrm{NH}_{4}{ }^{+}$,
Table 2 Varimax rotated factor loadings, total variance and possible sources over Europe

\begin{tabular}{|c|c|c|c|c|c|}
\hline Europe & $F 1$ & $F 2$ & F3 & $F 4$ & F5 \\
\hline $\mathrm{Na}^{+}$ & 0.26 & 0.87 & 0.27 & -0.07 & 0.12 \\
\hline $\mathrm{K}^{+}$ & 0.14 & 0.14 & 0.09 & 0.02 & 0.98 \\
\hline $\mathrm{Ca}^{2+}$ & 0.70 & 0.22 & 0.52 & 0.20 & 0.04 \\
\hline $\mathrm{Mg}^{2+}$ & 0.29 & 0.39 & 0.82 & 0.11 & 0.13 \\
\hline $\mathrm{SO}_{4}{ }^{2-}$ & 0.76 & 0.51 & 0.10 & 0.17 & 0.07 \\
\hline $\mathrm{Cl}^{-}$ & 0.27 & 0.89 & 0.20 & 0.07 & 0.11 \\
\hline $\mathrm{NO}_{3}^{-}$ & 0.09 & 0.01 & 0.07 & 0.99 & 0.02 \\
\hline $\mathrm{NH}_{4}^{+}$ & 0.89 & 0.19 & 0.17 & 0.05 & 0.15 \\
\hline $\begin{array}{l}\% \text { Total vari- } \\
\text { ance }\end{array}$ & 26.47 & 25.71 & 13.70 & 12.92 & 12.84 \\
\hline $\begin{array}{l}\text { Possible } \\
\text { source }\end{array}$ & $\begin{array}{l}\text { Anthropo- } \\
\text { genic and } \\
\text { mixed }\end{array}$ & Marine & Terrestrial & Traffic & $\begin{array}{l}\text { Biomass } \\
\text { burning } \\
\text { and fertili- } \\
\text { sation }\end{array}$ \\
\hline
\end{tabular}

Principal Component Analysis (PCA) has been applied to precipitation chemistry data, in order to identify possible sources of pollutants and to reveal the important relationships amongst variables

The italic values indicate the significant loadings in case of each factor

$\mathrm{SO}_{4}^{2-}(R=0.73)$ and $\mathrm{NH}_{4}{ }^{+}, \mathrm{NO}_{3}(R=0.71)$ presented similar values, it can be said that $\left(\mathrm{NH}_{4}\right)_{2} \mathrm{SO}_{4}, \mathrm{NH}_{4} \mathrm{HSO}_{4}$ and $\mathrm{NH}_{4} \mathrm{NO}_{3}$ have equal contributions [44] to the overall precipitation chemistry of the studied European countries. The ratio between the above-mentioned species can differ from region to region. The significantly positive correlation between $\mathrm{Na}^{+}$and $\mathrm{Cl}^{-}(R=0.88$-Europe and Northern Europe, $R=0.94-$ Western Europe, $R=0.82-$ Southern Europe, $R=0.89-$ Central East Europe) indicates that probably not only the major part of these ions originated from sea salt, but chloride may also be present in precipitation from mofette emanations, mineral springs and salt mines [30].

\section{Principal Component Analysis}

Principal Component Analysis (PCA) has been applied to precipitation chemistry data, in order to identify the possible sources of pollutants and to reveal the important relationships amongst variables [54], summarising the patterns of correlations amongst variables and reducing a large number of variables to a smaller number of factors [27].

The rainwater air pollutants may have natural, anthropogenic or mixed origins, depending on their sources or the sources of their precursors [55]. Table 2 presents the Varimax rotated factor loading patterns, with five major components that were extracted accounting for $91.64 \%$ of the total variance.

The first factor explained the $26.47 \%$ of the total variance having high loadings on $\mathrm{NH}_{4}{ }^{+}, \mathrm{SO}_{4}^{2-}$ and $\mathrm{Ca}^{2+}$, indicating the influence of anthropogenic activities, such as industrial emissions or the presence of open quarries, the 
use of fertilisers in agriculture [56], and wind-blown soil dust [57]; therefore, it can be attributed to mixed sources with significant anthropogenic impact. The presence of anthropogenic $\mathrm{NH}_{4}{ }^{+}$in rainwater can be attributed to agricultural $\mathrm{NH}_{3}$ emissions, from cattle waste deposits, natural and chemical fertilisers [41, 58]; to biomass combustion and wildfires [59], having a particularly large contribution across Western and Central East Europe [55]. The increased occurrence and severity of wildfires in the last decades are known as a large contributor to the sources of ammonium in precipitation via PM emissions [60].

The interconnection between $\mathrm{NH}_{4}{ }^{+}$and $\mathrm{SO}_{4}^{2-}$ is derived from acidic pollutants emitted to the atmosphere through industrial activities, enhancing the occurrence of aerosols containing $\left(\mathrm{NH}_{4}\right)_{2} \mathrm{SO}_{4}$ and $\mathrm{NH}_{4} \mathrm{HSO}_{4}$ [27]. The association of $\mathrm{Ca}^{2+}$ and $\mathrm{SO}_{4}^{2-}$ can be accounted to the presence of $\mathrm{CaSO}_{4}$. The sources of dissolved $\mathrm{CaSO}_{4}$ in rainwater can be due to the neutralisation reactions between carbonate minerals and sulphuric acid, to the dissolution of gypsum or anhydrite, and to the crystallisation of gypsum in the atmosphere [61].

The second factor is attributed to maritime sources, presenting high loads of $\mathrm{Na}^{+}$and $\mathrm{Cl}^{-}$and explaining the $25.71 \%$ of the total variance. The influence of sea salts is significant due to the position of the European continent, being surrounded by seas and oceans.

The third factor is represented by the $13.70 \%$ of the total variance, being largely influenced by high loadings on $\mathrm{Ca}^{2+}$ and $\mathrm{Mg}^{2+}$, showing the contribution of crustal sources. The above-mentioned ions originate from the dissolution of dolomites and limestone, taking part in the neutralisation process as suspended $\mathrm{CaCO}_{3}$ and $\mathrm{MgCO}_{3}$ [30]. Also, chemical weathering of silicates can produce sodium ions that have a significant contribution to the neutralisation process.

Traffic is a major source of $\mathrm{NO}_{3}[55,62]$; therefore, the fourth factor that exhibited a high loading of nitrate and the $12.92 \%$ of the total variance is attributed to vehicular emission.

The high loading of $\mathrm{K}^{+}$explaining $12.84 \%$ of the total variance in case of the fifth factor indicates biomass burning as a possible source of potassium [63, 64]. According to Khare et al [65], potassium may be considered as a chemical signature of biomass burning, and is also present in complex chemical fertilisers, such as NPK $[41,46]$.

\section{Conclusions}

The chemical compositions of rainwater, $\mathrm{pH}$ variations, acidifying and neutralising processes, wet deposition rates and source contributions were determined in 27 European countries over a period of 18 years. The main conclusion of this study regarding the precipitation chemistry of the European continent during the studied period is represented by the relative homogenous distribution of the analysed chemical species, which is most likely due to the unitary economic development and to the implementation of common European policies in the field of environmental protection. Results showed the local characteristics, that are often diminished or enhanced by the dominant atmospheric circulations, loaded with different pollutants originating from neighbouring regions. Wet deposition rates also reflect the climatic influences and the local and regional economic characteristics of different regions from Europe. Enrichment factors, Spearman's rank correlation coefficients and the Principal Component Analysis highlighted that the precipitation chemistry of Europe is mainly controlled by anthropogenic influences. Sulphate and nitrate, that largely contribute to the rainwater's acidity, originate from industrial activities and traffic; ammonium and potassium can be attributed to biomass combustion, wildfires and agricultural activities, such as natural and chemical fertilisers. Magnesium and calcium are tracers of terrestrial sources, whilst chloride and potassium represent the maritime influence. The interconnection between rainwaters, slightly acidic and acidic $\mathrm{pH}$, and the ionic concentrations of neutralising compounds in precipitation leads to the conclusion that acidic species are more predominant in the atmosphere of the European continent than neutralising ones. The results showed that the main acidifying agents are sulphur and nitrogen compounds that originate from different industrial and agricultural activities, including traffic emissions and farming. Exposure to air pollutants and to precipitation containing sulphur and nitrogen compounds greatly affects the ecosystem and the environment, also damaging vegetation and fauna, leading to several environmental impacts, heavily influencing the quality of water and soil. Ammonia and nitrogen oxides are considered as the most harmful air pollutants in terms of damage to ecosystems [15]. The above-mentioned compounds $\left(\mathrm{NH}_{3}\right.$ and $\mathrm{NO}_{x}$ ) introduce large amounts of nutrient nitrogen into terrestrial and aquatic ecosystems, leading to eutrophication that may cause changes in species diversity and invasion of new species [15]. Nitrogen oxides along with sulphur dioxide also contribute to the acidification process of soil, lakes and rivers, causing biodiversity loss. According to the 2018 Report of the European Environmental Agency, the annual limit value for nitrogen dioxide continues to be widely exceeded over Europe. Whilst in case of sulphur dioxide, even if over the past three decades $\mathrm{SO}_{x}$ emissions considerably reduced, due to their higher acidifying potential in comparison with $\mathrm{NO}_{x}$, sulphur oxides still have a significant contribution 
to acidification. Therefore, we consider that it is of great importance for policy and decision makers to pay attention to the pollutant concentrations of these acidifying compounds, and which dissolved in rainwater may have more immediate effects of the environment.

\section{Abbreviations}

EU: Europe; CE-EU: Central East Europe; N-EU: Northern Europe; S-EU: Southern Europe; W-EU: Western Europe; VWM: volume-weighted mean; FA: fractional acidity; NF: neutralising factor; NFs: neutralising factors; NP: neutralising potential; AP: acidic potential; AAl: ammonium availability index; WD: wet deposition; EFs: enrichment factors; EF: enrichment factor; SSF: sea salt fraction; NSSF: non-sea salt fraction; PCA: Principal Component Analysis; NPK: a complex fertiliser composed from nitrogen, phosphorus and potassium; EMEP: European Monitoring and Evaluation Programme; EEA: European Environment Agency.

\section{Acknowledgements}

The authors gratefully acknowledge the source of precipitation chemistry data on page 92 of Vet et al. [8] Atmospheric Environment, 93, http://dx.doi. org/10.1016/j.atmosenv.2013.10.060. We acknowledge the E-OBS dataset from the EU-FP6 project UERRA (http://www.uerra.eu) and the Copernicus Climate Change Service, and the data providers in the ECA\&D project (https://www. ecad.eu).

\section{Authors' contributions}

Conceptualisation: RS; methodology: ÁK, RS, MVB, IAN, ZsB; writing: ÁK; supervision: RS, MVB. All authors read and approved the final manuscript.

\section{Funding}

Not applicable.

\section{Availability of data and materials}

The precipitation chemistry data used in the present study were downloaded from the GAW World Data Centre for Precipitation Chemistry, that is publicly available at http://wdcpc.org. The annual data of precipitation amount used in this study were extracted from E-OBS raster dataset (version 19.0). E-OBS data are freely available at http://www.ecad.eu.

\section{Ethics approval and consent to participate}

Not applicable.

\section{Consent for publication}

Not applicable.

\section{Competing interests}

The authors declare that they have no competing interests.

\section{Author details}

1 Faculty of Natural Sciences, Doctoral School of Chemistry, University of Pécs, Ifúság 6, Pécs 7624, Hungary. ${ }^{2}$ Meteo Romania (National Meteorological Administration), Soseaua București-Ploiești 97, 013686 Bucharest, Romania. ${ }^{3}$ Faculty of Geography and Geology, Doctoral School of Geosciences, Alexandru loan Cuza University, Bulevardul Carol I 11, 700506 lași, Romania. ${ }^{4}$ Department of Bioengineering, Faculty of Economics, Socio-Human Science and Engineering, Sapientia Hungarian University of Transylvania, Piaţa Libertăţii 1, 530104 Miercurea Ciuc, Romania. ${ }^{5}$ Institute for Research and Development in Cinegetics and Mountain Resources, Progresului 35B, 530240 Miercurea Ciuc, Romania.

Received: 19 April 2019 Accepted: 20 July 2019

Published online: 01 August 2019

\section{References}

1. Galloway JN, Likens GE, Hawley ME (1984) Acid precipitation: natural versus anthropogenic components. Science. 226:829-831. https://doi. org/10.1126/science.226.4676.829
2. Kulshrestha UC, Sarkar AK, Srivastava SS, Parashar DC (1996) Investigation into atmospheric deposition through precipitation studies at New Delhi (India). Atmos Environ 30:4149-4154. https://doi.org/10.1016/13522310(96)00034-9

3. Tiwari S, Singh JV, Momin GA et al (2001) Influence of calcium and sulphate on the pH of rainwater at Delhi. Indian J Radio Sp Phys 30:325-331

4. Das R, Das SN, Misra VN (2005) Chemical composition of rainwater and dustfall at Bhubaneswar in the east coast of India. Atmos Environ 39:5908-5916. https://doi.org/10.1016/j.atmosenv.2005.06.030

5. Tiwari S, Chate DM, Bisht DS et al (2012) Rainwater chemistry in the North Western Himalayan Region, India. Atmos Res 104-105:128-138. https:// doi.org/10.1016/j.atmosres.2011.09.006

6. Celle-Jeanton H, Travi Y, Loyle-Pilot MD et al (2009) Rainwater chemistry at a Mediterranean inland station (Avignon, France): local contribution versus long-range supply. Atmos Res 91:118-126. https://doi.org/10.1016/j. atmosres.2008.06.003

7. Aiuppa A, Bonfanti P, D’Alessandro W (2003) Rainwater chemistry at Mt. Etna (Italy): natural and anthropogenic sources of major ions. J Atmos Chem 46:89-102

8. Vet R, Artz RS, Carou S et al (2014) A global assessment of precipitation chemistry and deposition of sulfur, nitrogen, sea salt, base cations, organic acids, acidity and pH, and phosphorus. Atmos Environ 93:3-100. https://doi.org/10.1016/j.atmosenv.2013.10.060

9. Zhang M, Wang S, Wu F et al (2007) Chemical compositions of wet precipitation and anthropogenic influences at a developing urban site in southeastern China. Atmos Res 84:311-322. https://doi.org/10.1016/j. atmosres.2006.09.003

10. Wu Y, Xu Z, Liu W et al (2016) Chemical compositions of precipitation at three non-urban sites of Hebei Province, North China: influence of terrestrial sources on ionic composition. Atmos Res 181:115-123. https:// doi.org/10.1016/j.atmosres.2016.06.009

11. Mouli PC, Mohan SV, Reddy SJ (2005) Rainwater chemistry at a regional representative urban site: influence of terrestrial sources on ionic composition. Atmos Environ 39:999-1008. https://doi.org/10.1016/j.atmos env.2004.10.036

12. Whelpdale DM, Kaiser M. (1996) Global Acid Deposition Assessment

13. Whelpdale DM, Summers PW, Sanhueza E (1997) A global overview of atmospheric acid deposition fluxes. Environ Monit, Assess

14. Dentener F, Drevet J, Lamarque JF et al (2006) Nitrogen and sulfur deposition on regional and global scales: a multimodel evaluation. Global Biogeochem Cycles. https://doi.org/10.1029/2005GB002672

15. European Environmental Agency (EEA) (2018) Air quality in Europe-2018 report

16. Maas R, Grennfelt RP (2016) Towards Cleaner Air, Scientific Assessment Report 2016: summary for policymakers. EMEP steer body work Gr Eff Conv long-range transbound air pollution, Oslo 16. https://doi. org/10.1016/S0140-6736(54)91963-7

17. Fagerli H, Tsyro S, Denby BR, et al (2017) Transboundary particulate matter, photo-oxidants, acidifying and eutrophying components-EMEP Status Report 2017. EMEP Status Rep 2017

18. Cornes RC, van der Schrier G, van den Besselaar EJM, Jones PD (2018) An ensemble version of the E-OBS temperature and precipitation data sets. J Geophys Res Atmos. https://doi.org/10.1029/2017JD028200

19. Bisht DS, Srivastava AK, Joshi $\mathrm{H}$ et al (2017) Chemical characterization of rainwater at a high-altitude site "Nainital" in the central Himalayas, India. Environ Sci Pollut Res 24:3959-3969. https://doi.org/10.1007/s1135 6-016-8093-z

20. Anatolaki C, Tsitouridou R (2009) Relationship between acidity and ionic composition of wet precipitation. A two years study at an urban site, Thessaloniki, Greece. Atmos Res 92:100-113. https://doi.org/10.1016/j. atmosres.2008.09.008

21. Rao PSP, Tiwari S, Matwale JL et al (2016) Sources of chemical species in rainwater during monsoon and non-monsoonal periods over two mega cities in India and dominant source region of secondary aerosols. Atmos Environ 146:90-99. https://doi.org/10.1016/j.atmosenv.2016.06.069

22. Xu Z, Wu Y, Liu WJ et al (2015) Chemical composition of rainwater and the acid neutralizing effect at Beijing and Chizhou city, China. Atmos Res 164-165:278-285. https://doi.org/10.1016/j.atmosres.2015.05.009

23. Tang A, Zhuang G, Wang Y et al (2005) The chemistry of precipitation and its relation to aerosol in Beijing. Atmos Environ 39:3397-3406. https://doi. org/10.1016/j.atmosenv.2005.02.001 
24. Huang K, Zhuang G, Xu C et al (2008) The chemistry of the severe acidic precipitation in Shanghai, China. Atmos Res 89:149-160. https://doi. org/10.1016/j.atmosres.2008.01.006

25. Tiwari S, Hopke PK, Thimmaiah D et al (2016) Nature and sources of ionic species in precipitation across the indo-gangetic plains, India. Aerosol Air Qual Res 16:943-957. https://doi.org/10.4209/aaqr.2015.06.0423

26. Harrison RM, Pio CA (1983) Size-differentiated composition of inorganic atmospheric aerosols of both marine and polluted continental origin. Atmos Environ. 1:1. https://doi.org/10.1016/0004-6981(83)90180-4

27. Balasubramanian R, Victor T, Chun N (2001) Chemical and statistical analysis of precipitation in Singapore. Water Air Soil Pollut 130:451-456. https ://doi.org/10.1023/A:1013801805621

28. Chate DM, Devara PCS (2009) Acidity of raindrop by uptake of gases and aerosol pollutants. Atmos Environ 43:1571-1577. https://doi. org/10.1016/j.atmosenv.2008.06.031

29. Kaya G, Tuncel G (1997) Trace element and major ion composition of wet and dry depositon in Ankara, Turkey. Atmos Environ 31:3985-3998. https ://doi.org/10.1016/S1352-2310(97)00221-5

30. Szép R, Mateescu E, Niță A et al (2018) Effects of the Eastern Carpathians on atmospheric circulations and precipitation chemistry from 2006 to 2016 at four monitoring stations (Eastern Carpathians, Romania). Atmos Res 214:311-328. https://doi.org/10.1016/J.ATMOSRES.2018.08.009

31. Te Chang C, Wang CP, Chuan JH et al (2017) Trends of two decadal precipitation chemistry in a subtropical rainforest in East Asia. Sci Total Environ 605-606:88-98. https://doi.org/10.1016/j.scitotenv.2017.06.158

32. Roy A, Chatterjee A, Tiwari S et al (2016) Precipitation chemistry over urban, rural and high altitude Himalayan stations in eastern India. Elsevier, New York

33. Kumar R, Rani A, Singh SP et al (2002) A long term study on chemical composition of rainwater at Dayalbagh, a suburban site of semiarid region. J Atmos Chem 41:265-279. https://doi.org/10.1023/A:1014955715 633

34. Khemani LT, Momin GA, Rao PSP et al (1994) Atmospheric pollutants and their influence on acidification of rain water at an industrial location on the West Coast OF India. Atmos Environ 28:3145-3154. https://doi. org/10.1016/1352-2310(94)00148-E

35. Seinfeld JH (1986) Atmospheric chemistry and physics of air pollution

36. Duan FK, Liu XD, He KB et al (2003) Atmospheric aerosol concentration level and chemical characteristics of water-soluble ionic species in wintertime in Beijing, China. J Environ Monit 5:569-573. https://doi. org/10.1039/b303691j

37. Behera SN, Sharma M (2010) Investigating the potential role of ammonia in ion chemistry of fine particulate matter formation for an urban environment. Sci Total Environ 408:3569-3575. https://doi.org/10.1016/j.scito tenv.2010.04.017

38. Chu SH (2004) PM2.5 episodes as observed in the speciation trends network. Atmos Environ 38:5237-5246. https://doi.org/10.1016/j.atmos env.2004.01.055

39. Cao YZ, Wang S, Zhang G et al (2009) Chemical characteristics of wet precipitation at an urban site of Guangzhou, South China. Atmos Res 94:462-469. https://doi.org/10.1016/j.atmosres.2009.07.004

40. Xiao J (2016) Chemical composition and source identification of rainwater constituents at an urban site in Xian. Environ Earth Sci 75:1-12. https ://doi.org/10.1007/s12665-015-4997-z

41. Szép R, Bodor Z, Miklóssy l et al (2019) Influence of peat fires on the rainwater chemistry in intra-mountain basins with specific atmospheric circulations (Eastern Carpathians, Romania). Sci Total Environ 647:275289. https://doi.org/10.1016/j.scitotenv.2018.07.462

42. Yatkin S, Adali M, Bayram A (2016) A study on the precipitation in Izmir, Turkey: chemical composition and source apportionment by receptor models. J Atmos Chem 73:241-259. https://doi.org/10.1007/s1087 4-015-9325-1

43. Kulshrestha UC, Kulshrestha MJ, Sekar R et al (2003) Chemical characteristics of rainwater at an urban site of south-central India. Atmos Environ 37:3019-3026. https://doi.org/10.1016/S1352-2310(03)00266-8

44. Lu X, Li LY, Li N et al (2011) Chemical characteristics of spring rainwater of Xi'an city, NW China. Atmos Environ 45:5058-5063. https://doi. org/10.1016/j.atmosenv.2011.06.026

45. Barbalace K (2015) Periodic table of elements. EnvironmentalChemistry. com. EnvironmentalChemistry.com. https://doi.org/10.1134/S106193480 7090018
46. Zunckel M, Saizar C, Zarauz J (2003) Rainwater composition in northeast Uruguay. Atmos Environ 37:1601-1611. https://doi.org/10.1016/S1352 $-2310(03) 00007-4$

47. Herut B, Starinsky A, Katz A, Rosenfeld D (2000) Relationship between the acidity and chemical composition of rainwater and climatological conditions along a transition zone between large deserts and Mediterranean climate, Israel. Atmos Environ 34:1281-1292. https://doi.org/10.1016/ S1352-2310(99)00291-5

48. Xiao H-Y, Shen C-Y, Xiao H-W et al (2017) Atmospheric aerosol compositions over the South China Sea: temporal variability and source apportionment. Atmos Chem Phys 17:3199-3214. https://doi.org/10.5194/ acp-17-3199-2017

49. Xu Z, Tang Y, Ji J (2012) Chemical and strontium isotope characterization of rainwater in Beijing during the 2008 Olympic year. Atmos Res 107:115-125. https://doi.org/10.1016/j.atmosres.2012.01.002

50. Xu Z, Li Y, Tang Y, Han G (2009) Chemical and strontium isotope characterization of rainwater at an urban site in Loess Plateau, Northwest China. Atmos Res 94:481-490. https://doi.org/10.1016/j.atmosres.2009.07.005

51. Niu H, He Y, Lu XX et al (2014) Chemical composition of rainwater in the Yulong Snow Mountain region, Southwestern China. Atmos Res 144:195-206. https://doi.org/10.1016/j.atmosres.2014.03.010

52. Rao W, Han G, Tan H et al (2017) Chemical and Sr isotopic characteristics of rainwater on the Alxa Desert Plateau, North China: implication for air quality and ion sources. Atmos Res 193:163-172. https://doi. org/10.1016/j.atmosres.2017.04.007

53. Li Y-C, Zhang M, Shu M et al (2016) Chemical characteristics of rainwater in Sichuan basin, a case study of Ya'an. Environ Sci Pollut Res. 1:1. https:// doi.org/10.1007/s11356-016-6363-4

54. Hu GP, Balasubramanian R, Wu CD (2003) Chemical characterization of rainwater at Singapore. Chemosphere 51:747-755. https://doi. org/10.1016/50045-6535(03)00028-6

55. European Environmental Agency (EEA) (2015) Air quality in Europe-2015 report

56. Niu H, He Y, Kang S et al (2016) Chemical compositions of snow from Mt. Yulong, southeastern tibetan plateau. J Earth Syst Sci 125:403-416. https ://doi.org/10.1007/s12040-016-0670-5

57. Tiwari S, Srivastava MK, Bisht DS (2008) Chemical composition of rainwater in Panipat, an industrial city in Haryana. Indian J Radio Sp Phys 37:443-449

58. Kim M-K, Lee J-S, Jung G-B et al (2013) Chemical characterization of rainwater over Suwon region during farming and non-farming periods. J Agric Chem Environ 02:1-7. https://doi.org/10.4236/jacen.2013.21001

59. Schlesinger WH, Hartley AE (1992) A global budget for atmospheric NH3. Biogeochemistry 15:191-211. https://doi.org/10.1007/BF00002936

60. Knorr W, Dentener F, Lamarque JF et al (2017) Wildfire air pollution hazard during the 21st century. Atmos Chem Phys 17:9223-9236. https://doi. org/10.5194/acp-17-9223-2017

61. Herut B, Spiro B, Starinsky A, Katz A (1995) Sources of sulfur in rainwater as indicated by isotopic $\delta 34 \mathrm{~S}$ data and chemical composition, Israel. Atmos Environ 29:851-857. https://doi.org/10.1016/1352-2310(94)00307-7

62. Wang H, Han G (2011) Chemical composition of rainwater and anthropogenic influences in Chengdu, Southwest China. Atmos Res 99:190-196. https://doi.org/10.1016/j.atmosres.2010.10.004

63. Lara LB, Artaxo P, Martinelli LA et al (2001) Chemical composition of rainwater and anthropogenic influences in the Piracicaba River Basin, Southeast Brazil. Atmos Environ 35:4937-4945

64. Budhavant KB, Rao PSP, Safai PD, Ali K (2011) Influence of local sources on rainwater chemistry over Pune region, India. Atmos Res 100:121-131. https://doi.org/10.1016/j.atmosres.2011.01.004

65. Khare P, Goel A, Patel D, Behari I (2004) Chemical characterization of rainwater at a developing urban habitat of Northern India. Atmos Res 69:135-145. https://doi.org/10.1016/j.atmosres.2003.10.002

\section{Publisher's Note}

Springer Nature remains neutral with regard to jurisdictional claims in published maps and institutional affiliations. 